\title{
The Determinants of AAOIFI Governance Disclosure in Islamic Banks
}

\author{
Tawida Elgattani \\ Researcher, Portsmouth Business School, University of Portsmouth \\ UP833978@myport.ac.uk
}

Khaled Hussainey

Professor of Accounting and Financial Management, Portsmouth Business School, University of Portsmouth

khaled.hussainey@port.ac.uk

\begin{abstract}
Purpose- We investigate the influence of corporate governance mechanisms on Accounting and Auditing Organization for Islamic Financial Institution (AAOIFI) governance disclosure in Islamic Banks.

Design/methodology/approach- To test our research hypotheses, we create a comprehensive AAOIFI governance disclosure index and use regression analysis for a sample of Islamic banks for the financial years within the period 2013-2015.
\end{abstract}

Findings- We find that audit committee size is the main determinant of the AAOIFI governance disclosure.

Originality/value- The research contributes to Islamic accounting literature, by identifying the driver for the AAOIFI governance disclosure for Islamic banks that mandatorily adopt AAOIFI standards.

Keywords- AAOIFI Governance Standards, Corporate Governance, Islamic Banks, Disclosure Paper type- Research paper. 


\section{Introduction}

Since the 2007 global financial crisis, a large number of studies have focused on corporate governance (CG) in financial institutions (Srairi, 2015). The concept of governance in English comes from the Greek word 'kybernan', which means to guide, steer or govern (Cadbury, 2002). This refers to the association between the governors and the governed, such as the association between the government and the public (Salin et al., 2017). The Organisation for Economic Co-operation and Development (OECD) has given a precise definition of CG (2004:11) "Corporate governance involves a set of relationships between a company's management, its board, its shareholders and other stakeholders. Corporate governance also provides the structure through which the objectives of the company are set, and the means of attaining those objectives and monitoring performance are determined. Good corporate governance should provide proper incentives for the board and management to pursue objectives that are in the interests of the company and its shareholders and should facilitate effective monitoring."

This definition of CG by OECD specifically focuses on the transparency of accounting disclosure (Grais and Pellegrini, 2006). CG has become an important factor, with the aim of providing better and effective safeguards to all stakeholders, and also to make sure that the market has no doubts, and research displays a positive relationship among CG and shares price (Hasan et al., 2017b).

Our paper is motivated by the rapid development of Islamic finance and the growing interests in the Islamic Financial Institutions (IFIs). These institutions are important, especially for Muslims, as they supply services that comply with Sharia principles, e.g. interest-free (ribabased) finance, and avoiding transactions which are prohibited by Sharia, such as alcohol, drugs and other activities that bring damage to society (Salin et al., 2017). IFIs should recognise society's interest (Bhatti and Bhatti, 2009) while directing businesses to earn a higher profit. For example, IFIs should disclose more information which is reliable and relevant, because this information assists all stakeholders in making their decision (Salin et al., 2017). Governance in Islam includes all Muslims' transactions because the resource of sharia is considered to be a trust from Allah (God) and an examination of their faith (Saeed, 1996). So, IFls have to be honest and fair between all stakeholders and shareholders. The definition of Sharia governance is a governance structure that confirms overall actions and business deals via IFIs are free from illegal elements, e.g. interest, uncertainty and other characteristics (Bahari and Baharudin, 2016).

We are motivated to focus on Islamic banks because the principles of Sharia make CG in these banks both unique and essential. Meanwhile, the CG of IFIs is a structure that permits the guarantee of duty to Islamic principles to ensure fairness to all stakeholders. Therefore, Sharia governance has a unique characteristic of the Islamic system of financial management. Accountability, transparency and adequate disclosure are three essential ingredients in CG. According to Baydoun and Willett (2000), the essential aim of corporate reporting from an Islamic viewpoint is that it exceeds other targets to permit Islamic institution to present their compliance with Islamic law. 
The lack of previous research that studies the impact of CG on AAOIFI governance disclosure in IBs also motivated us to explore this issue. There are a few studies that focus on the concept of AAOIFI governance disclosure in IBs (Abdullah, 2013; Haniffa and Hudaib, 2007). However, these studies have not considered all of the AAOIFI governance and have not examined all countries that mandatorily adopt AAOIFI standards. Therefore, this study attempts to fill this gap by examining the impact of CG mechanisms on AAOIFI governance disclosure in IBs. The uniqueness of AAOIFI governance standards and their interest to safeguard the Islamic banking industry by imposing a comprehensive governance standards this motived us to examine what drive banks to adopt these standards. Our findings provide practical implications to AAOIFI members as well as Islamic banks.

The remainder of the paper is structured as follows. Section two reviews relevant literature. Section three discusses the research method. Section four reports the main findings. Section five concludes and suggests lines for further studies.

\section{Literature Review}

According to Jensen and Meckling, (1976), good CG characteristics are needed to align the interest of directors with that of shareholders, and therefore minimise agency costs. IFIs usually face more agency problems than conventional banks (Safieddine, 2009). Antonio (2001) stated that agency problems also appear in the association between owners and IB agents. So, IFIs need good CG for many reasons. First, the problem of separation between owners and management, which based on agency theory, is a major factor in IBs compared with traditional banks. Also, IBs have more responsibility to shareholders and must make sure they are complying with Sharia (Safieddine, 2009; Sarker, 2000). Customers of IBs in Bahrain and Sudan are willing to withdraw their deposits if they discover a case of noncompliance with Sharia (Chapra and Ahmed, 2002). The consequence of non-compliance with Sharia in IBs could have a negative effect on their reputation, resulting in the loss of customers. To conform to the Sharia principles in IBs, there are important differences regarding agency structure in IBs compared to those seen in traditional banks (Zainuldain et al., 201). For example, the unique contractual arrangements of mudarabah and musharakah investment accounts, present various kinds of agency problems among investment account holders (IAHs) who have cash-flow rights and shareholders who own the control rights (Safieddine, 2009).

In general, agency theory suggested that good CG leads to decreases in agency costs, improved governance practice, disclosure and financial performance (Fama and Jensen, 1983; Khan et al., 2013). Thus, this theory is used to investigate the determinants of AAOIFI governance disclosure.

The next subsection shows the literature on CG mechanisms that may effect CG disclosure in IBs. These are an independent board, board size, board meeting, the duality of CEO position, audit committee size (ACs) and audit committee meeting (ACM).

\subsection{Corporate governance characteristics}

Better regulation of CG mechanisms needs a reasonable level of disclosure and sufficient information to decrease information asymmetries among whole parties in the company (Joshi et al., 2016). Additionally, a robust CG structure raises the confidence of investors, as 
their investment will be guaranteed by the internal safeguard and a controlling system to ensure prudence regarding management activities. Therefore, this leads to a high level of disclosure and transparency requirements from public interest (Joshi et al., 2016). Depending on the agency theory framework, the CG characteristics are introduced to reduce opportunist behaviours among managers, to decrease information asymmetry and to ensure that managers work in the interest of the shareholder. It can improve a firm's internal control and, consequently, develop the level of disclosure (Welker, 1995; Ho and Wong, 2001). Accordingly, it can be seen that CG characteristics could improve CG disclosure reporting. The following paragraphs review relevant literature.

\subsubsection{Independent directors (B.IND)}

Independent directors have received increased interest from CG regulations and academic research (Almanasir and Shivaraj, 2017; Ho and Wong, 2001). Also, academics have pointed out that independent directors can safeguard shareholders and assist in decreasing agency costs (Lipton and Lorsch, 1992). Fama (1980) argued that a board of directors is the primary internal control character for monitoring managers. Also, the existence of independent directors on the board may increase the quality of the financial statements (Peasnell et al., 2005). According to agency theory, independent directors are further capable of limiting managerial opportunities (Fama and Jensen, 1983). The theory also suggests that the presence of independent managers on the board can reduce information asymmetry (Allegrini and Greco, 2013). Most of the prior research was found to have a positive relationship among CG disclosure and independent directors such as Abdullah et al. (2015), their research examines the determinant of voluntary CG disclosure of 67 IBs in the Southeast Asian and GCC region. They found that board independent has a positive relationship with voluntary CG disclosure.

Similarly, Samaha et al. (2012) found that the higher ratio of board independent increases the level of disclosure in 100 Egyptian listed companies. Arcay and Vazquez (2005) reported a positive relationship between board independence and voluntary disclosure. Gisbert and Navallas (2013), study the relationship between voluntary disclosure and CG in a sample of 62 Spanish firms in 2005. They find that the ratio of independent directors is related with increased level of disclosure.

In addition, Haniffa and Cooke (2002), state that independent directors can help the board with their knowledge and experience. Similarly, Garcia-Meca and Sanchez-Ballesta (2010) found that independent directors provide a high level of protection to shareholders. However, Ho and Wong (2001) examined the association between the proportion of board independent and voluntary disclosure in a questionnaire survey sent to all chief financial officers in listed companies in Hong Kong. They found an insignificant association among disclosure and independent managers and they explain the reason for their result maybe companies in Hong Kong are probable to comply with mandatory disclosure only. Thus, based on agency theory, we hypothesise that:

$\mathrm{H}_{1}$ : There is a positive association between board independence and the level of AAOIFI governance disclosure. 


\subsubsection{Board size (B.SIZE)}

The board of directors (BOD) plays an essential role in $C G$ and contains an overall number of executive and non-executive managers on the board. Based on agency theory, board size is a potential variable of CG with regard to the monitoring of management performance (Allegrini and Greco, 2013). Also, the theory suggests that a large number of board directors affects the operation of managerial monitoring activities and control (Healy and Palepu, 2001). According to previous literature, board size affects the level of monitoring and disclosure (Rahma and Bukair, 2015). Also, previous studies found mixed results, as Ntim and Soobaroyen (2013), argue that the level of voluntary disclosure is positively influenced by increased managerial monitoring. Similarly, Al-Janadi et al. (2013), found that board size enhances further efficient decision-making and extends information dealing capabilities. Also, Wang and Hussainey (2013), indicate that firms with larger boards are more likely to disclose more information. Zaheer (2013), found that a larger board size positively influences the level of CG disclosure.

In contrast, others find no significant influence regarding board size on CG disclosure ( Hasan et al., 2017b; Arcay and Vazquez, 2005). According to agency theory the current research anticipates that a greater board size will increase board control. The consequence of this is an improvement in the level of disclosure in IBs. Based on agency theory, this study hypothesises that:

\section{H2: There is a positive relationship between board size and the level of AAOIFI governance disclosure.}

\subsubsection{Board meeting (B.M)}

The board's performance is assessed by the number of meetings held during the year (Albawwat and Hussein , 2015). Kanagaretnam et al. (2007), suggested that the more board meetings that are held throughout the year, the more the company is able to execute a supervisory role better and to reduce information asymmetry. Agency theory suggested that the frequency of board meetings affects the strength of the CG component (Khanchel, 2007). More board meetings allow members to supervise better managers, which leads managers to disclose high-disclosure information to stakeholders (Lipton and Lorsch, 1992). Laksmana, (2008), stated that more board meetings lead companies to be more likely to show an increased level of transparency.

Similarly, Hasan (2011) argued that a high meeting frequency would tend to signal achievement and provide extra information to all stakeholders. Accordingly, several previous studies found an positive relationship between board meetings and financial reporting and disclosure Such as Albawwat and Hussein (2015) who study the relationship between board meeting and voluntary disclosure in interim financial reports in Jordanian listed firms for the 2009-2013. They found that the disclosure level in Jordan listed companies affected by the number of board meeting. While Fiori et al. (2016) examined the effectiveness of CG on voluntary disclosure in a sample of 35 companies that linked the Pilot programme in 2011 and a similar 137 firms that did not, they conclude that there is no association between a board meeting and the level of voluntary disclosure. Based on agency theory, this research hypothesises that: 
H3: There is a positive relationship between board meetings and the level of AAOIFI governance disclosure.

\subsubsection{Duality in position (CEO)}

When the chairman of the board is also the CEO, the role of duality in the position occurs (ElHalaby and Hussainey, 2016). The CEO is a significant factor of CG because of its sensitive characteristic, due to the relationship among the agents and owners (Krause et al., 2014). According to agency theory, CEO duality is viewed as harmful, because the agent may follow their self-interest at the expense of the owners. Also, the theory states that effective monitoring of management execution will be provided via separation between the two functions ( Haniffa and Cooke, 2002). According to Gul and Leung (2004: 356), "Firms with CEO duality are more likely to be associated with lower levels of voluntary disclosure since the board is less likely to be effective in monitoring management and ensuring a higher level of transparency". According to Donker and Zahir (2008), agency theory predicts that duality in position creates a single power for the CEO that influences the efficient control exercised by the board. Prior research provided mixed findings on the relationship among duality in a position and CG disclosure. Several studies found a negative relationship among the two variables: Ezat and El-Masry (2008), found that CEO is negatively correlated with corporate disclosure levels. In addition, Gisbert and Navallas (2013), studied the association between voluntary disclosure and CG in 62 non-financial Spanish companies listed on the Madrid stock market in 2005. They found that CEO is negatively associated with disclosure. This shows that duality in a position significantly decreases the disclosure of voluntary information.

However, other studies did not find an significant association between the two variables (Hasan et al., 2017b; Ho and Wong, 2001). While some studies found a positive relationship between the two variables, namely Wang and Hussainey (2013), who examined the impact of $C G$ on the level of voluntary disclosure and found a positive association between CEO and the level of voluntary disclosure. Also, Abdullah et al. (2015), investigated the determinants of voluntary CG disclosure practice about 67 IBs. The study found that the separation of the role between the board chair and CEO has a positive relationship with voluntary CG disclosure. This result suggests that good CG mechanisms improve the level of CG disclosure in their annual reports.

Peng et al. (2007) and Hashim and Devi (2008), suggest the two roles should be separated, for causes of independence. This research supposes that the separation roles of functions between the chair and chief executive will improve the monitoring clarity and decrease the interests of hiding information, resulting in improved CG disclosure in IBs. Based on agency theory, IBs without CEO duality issues are predicted to have a higher CG disclosure level. Thus, the study develops the following hypothesis:

H4: There is a negative relationship between CEO duality in a position and the level of AAOIFI governance disclosure.

\subsubsection{Audit committee size (ACS)}

Based on agency theory, companies with a larger ACS have a stronger incentive to maintain their independence and require more comprehensive disclosure standards (Fama, 1980). 
According to Mangena and Pike (2005), more effective control will be given to companies with larger ACs. Barako et al. (2006) asserted that ACS should lead to the integrity of the financial statements and monitoring of the firm's internal financial regulation and the development of corporate information disclosure. Also, Al-Janadi et al. (2013) assert that the role of the ACS is a central role to improve the level of disclosure in relation to the financial reports. Companies with a larger ACS are faithful to good quality financial performance (Abdullah, 2013). It can be argued that ACS can reduce agency conflicts by limiting the opportunistic behaviour of agents (Haniffa and Cooke, 2002).

Some previous studies found a positive association between ACS and CG disclosure. For example, Almanasir and Shivaraj (2017) examined the determinants of CG voluntary disclosure in 61 firms listed in Jordan from 2010 to 2014. They report that a positive relationship between ACS and voluntary CG disclosure. Joshi et al. (2012) find a positive relationship between ACS and CG disclosure practice using 850 firms listed on the Malaysia Stock Market in 2013. Recently, Sulub et al. (2018) found that IBs which have an established AC have a higher level of CG disclosure.

Meanwhile, Othman et al. (2014) found that there is an insignificant relationship between ACS and voluntary ethics disclosure in a sample of 94 firms listed on Malaysia stock market.

According to agency theory, the current research expects that a larger ACS will increase board-controlling capabilities and, thus, give a positive impact on the disclosure level practice in IBs. Therefore, the study hypothesises that:

H5: There is a positive association between ACS and the level of AAOIFI governance disclosure.

\subsubsection{Audit committee meeting (ACM)}

Greco (2011), stated that the frequency of ACM leads members to an accurate decision about a firm's accounting principles, disclosures and evaluation. Also, Raghunandan et al. (2001), stated that audit committees that meet frequently are more likely to be well informed, more careful and more knowledgeable about the existing accounting and auditing issues, in relation to achieving their duties. Prior research has suggested that the number of meetings impacts on there being enough time to control and gain compliance with responsibilities of financial performance (Li et al., 2012). Gray et al. (1995) argued that to be responsible, managers need to supply financial and non-financial information to their stakeholders.

Some prior studies found an insignificant relationship between ACM and level of disclosure such as Othman et al. (2014) and report that ACM insignificant relationship with voluntary ethics disclosure in 94 companies listed in Malaysia Stock Exchange in one the year 2011.

Based on agency theory, the frequency of ACMs may provide a level of control in relation to the activities carried out by IBs and, therefore, provide better CG disclosure within their annual reports. Thus, it is hypothesised that:

H6: There is a positive relationship between the ACM and the level of AAOIFI governance disclosure. 


\subsection{Bank Characteristics as a control variables}

Following prior research, we control for banks characteristics such as size (e.g. El-Halaby and Hussainey, 2016; and Elfeky, 2017 ); liquidity (e.g. Elzahar and Hussainey ,2012); leverage( e.g. Elfeky, 2017); Asset growth (e.g. Nejati ,2013)

\section{Research Methodology and Sample Selection}

\subsection{Research Methodology}

The current study uses the following OLS regression model:

$$
Y=\beta_{0}+\beta_{1} X_{1}+\beta_{2} X_{2}+\ldots \ldots \ldots . .+\beta_{21} X_{21}+\varepsilon
$$

Where:

$\mathrm{Y}=\mathrm{AAOIFI}$ governance disclosure level (dependent variable)

$\mathrm{X}_{1}-\mathrm{X}_{6}=$ independent $\mathrm{CG}$ variables consist (are as shown in Table 1 below)

$\mathrm{X}_{7}-\mathrm{X}_{21}=$ control variables (are as shown in Table 1 below)

$\beta_{0}=$ intercept

$\beta_{1} \ldots . . . \beta_{21}=$ regression model coefficients (parameters)

$\varepsilon=$ random error (the differences between the predicted and observed value of the AAOIFI governance disclosure in sample banks)

1TABLE 1: SUMmARY OF DEPENDENT, INDEPENDENT AND CONTROL VARIABLES

\begin{tabular}{|l|l|l|l|}
\hline Variable & Definition & Measurement & Source \\
\hline $\mathrm{Y}$ & $\begin{array}{l}\text { CG disclosure } \\
\text { of AAOIFI } \\
\text { governance score } \\
\text { by IBs (Dis level) }\end{array}$ & $\begin{array}{l}\text { The percentage of } \\
\text { AAOIFI governance } \\
\text { information } \\
\text { disclosure by IBs }\end{array}$ & Annual report \\
\hline $\mathrm{X}_{1}$ & $\begin{array}{l}\text { Board } \\
\text { independence } \\
\text { (B.IND) }\end{array}$ & $\begin{array}{l}\text { The proportion of } \\
\text { independent non- } \\
\text { executive directors } \\
\text { on the board }\end{array}$ & Annual report \\
\hline $\mathrm{X}_{2}$ & Board size (B.SIZE) & $\begin{array}{l}\text { Number of board } \\
\text { members }\end{array}$ & Annual report \\
\hline $\mathrm{X}_{3}$ & $\begin{array}{l}\text { Board meeting } \\
\text { (B.M) }\end{array}$ & $\begin{array}{l}\text { The whole number } \\
\text { of board meetings } \\
\text { over the year }\end{array}$ & Annual report \\
\hline $\mathrm{X}_{4}$ & $\begin{array}{l}\text { Audit committee } \\
\text { size (ACs) }\end{array}$ & $\begin{array}{l}\text { The whole number } \\
\text { of AC members }\end{array}$ & Annual report \\
Audit committee & $\begin{array}{l}\text { The whole number } \\
\text { of AC meetings } \\
\text { over the year }\end{array}$ & Annual report \\
\hline $\mathrm{X}_{5}$ & $\begin{array}{l}\text { Duality in position } \\
\text { (CEO) }\end{array}$ & $\begin{array}{l}\text { 1 chairman and } \\
\text { CEO are different; } 0 \\
\text { = chairman and } \\
\text { CEO are the same }\end{array}$ & Annual report \\
\hline $\mathrm{X}_{6}$ & & & \\
\hline
\end{tabular}




\begin{tabular}{|l|l|l|l|}
\hline $\mathrm{X}_{7}$ & Firm size(F.SIZE) & $\begin{array}{l}\text { The natural } \\
\text { logarithm of the } \\
\text { firms' total assets }\end{array}$ & $\begin{array}{l}\text { Fitch Connect } \\
\text { (balance sheet and } \\
\text { income statement) }\end{array}$ \\
\hline $\mathrm{X}_{8}$ & Liquidity (LIQ) & $\begin{array}{l}\text { Current ratio }= \\
\text { current total asset } \\
\text { to current total } \\
\text { liability }\end{array}$ & $\begin{array}{l}\text { Fitch Connect } \\
\text { (balance sheet and } \\
\text { income statement) }\end{array}$ \\
\hline $\mathrm{X}_{9}$ & Leverage(LEV) & $\begin{array}{l}\text { Long-term debt to } \\
\text { total equity }\end{array}$ & $\begin{array}{l}\text { Fitch Connect } \\
\text { (balance sheet and } \\
\text { income statement) }\end{array}$ \\
\hline $\mathrm{X}_{10}$ & $\begin{array}{l}\text { Asset growth } \\
\text { (A.GRO) }\end{array}$ & $\begin{array}{l}\text { Firm asset-growth } \\
\text { ratio }\end{array}$ & $\begin{array}{l}\text { Fitch Connect } \\
\text { (balance sheet and } \\
\text { income statement) }\end{array}$ \\
\hline $\mathrm{X}_{11 \_} \mathrm{X}_{13}$ & Year dummy & & \\
\hline $\mathrm{X}_{14-} \mathrm{X}_{21}$ & Country dummy & & \\
\hline
\end{tabular}

\subsection{Sample and Data}

The sample includes all IBs that have mandatorily adopted AAOIFI standards. There are ten countries that have mandatorily adopted AAOIFI standards "Bahrain, Syria, Qatar, Sudan, Tunisia, Jordan, Lebanon, Palestine, Oman and Mauritius" (Al Qamashoui and Hussainey, 2016). However, the study excludes IBs in Lebanon, Tunisia and some banks from Sudan, because we did not have access to these banks' annual reports and, despite sending emails to these banks, they did not reply. To measure the levels of governance disclosure, we aim to collect annual reports from years 2011 onwards. Unfortunately, annual reports for years 2011 and 2012 were not available for a large sample of banks. We therefore started our analysis from year 2013. We end our analysis in 2015 as it was the most recent year at the time of the analysis.

\section{Results}

\subsection{Descriptive analysis}

Table 2 highlights that the mean value of the level of AAOIFI governance disclosure is about $33 \%$. This means that $33 \%$ of the AAOIFI governance disclosure items in the checklist are disclosed, on average, per annual report. The minimum value is about 0.04 , and the maximum value is .70 for the disclosure level, and this indicates that several annual reports are disclosed a little information, approximately $4 \%$ of the AAOIFI governance disclosure items, whereas there are others that disclose much more, namely $70 \%$ of the AAOIFI governance disclosure items. This reveals that the level of AAOIFI governance disclosure in IBs is weak.

Regarding independent variables, the average value of board independence is 0.25 Table 2 shows the less value for independent managers is 0.00 , with the most value of $100 \%$. This indicates that some IBs do not have independent directors such as the Liquidity Management Centre in Bahrain, while for others all members are independent directors, for instance, Bank Nizwa in Oman.

The mean value for Board size is about 9. The maximum value of 16 highlights that there are several assemblies with a larger number of board members, while the minimum value of 3 indicates that there are some boards with only three members. Board meetings has a 
minimum value of 2 indicating that some board members are meeting twice a year. Moreover, the maximum value of 10 . The mean value of the duality in position (CEO) variable is .98. This indicates the CEO and the chairman of the board are different in most of the IBs (98\%).

Table 2 also presents that the average value of the ACs variable is 3.33, with a minimum value of 3 and a maximum value of 6 . This indicates that several IBs have three audit committee members, while some have $A C$ with a maximum value of six members. The mean value of the ACM variable is 4.31 , with a minimum value of 1 and a maximum value of 8 . This indicates that the audit committee of the sample IBs is held, on average, four times per annum. With regard to the control variables (firm characteristics), namely leverage (LEVE), firm size (F.SIZE), liquidity (LQ) and asset growth (ASSET GTH), the mean values obtained are 22.7 for LEVE, 2,378.9 for F.SIZE, 4.15 for LQ, and 15.6 for ASSET GTH respectively.

2TABLE 2: Descriptive Statistics Of The VARIABles

\begin{tabular}{|c|c|c|c|c|c|}
\hline & $\mathrm{N}$ & Minimum & Maximum & Mean & Std. Deviation \\
\hline Disclosure level & 126 & .0357 & .70 & .332 & .1646 \\
\hline Board independence & 123 & $0.00 \%$ & $100.00 \%$ & $25.28 \%$ & $30.19 \%$ \\
\hline Board size & 124 & 3 & 16 & 8.92 & 2.247 \\
\hline Frequency of board meeting & 83 & 2 & 10 & 5.73 & 1.616 \\
\hline CEO duality & 123 & 0 & 1 & .98 & .155 \\
\hline ACs & 84 & 3 & 6 & 3.33 & .567 \\
\hline ACM & 80 & 1 & 8 & 4.31 & 1.208 \\
\hline Firm size & 126 & 7.33 & $22,893.2$ & $2,378.9$ & 4,090 \\
\hline Liquidity & 126 & .00 & 73.5 & 4.15 & 12.22 \\
\hline Asset growth & 124 & -34.9 & 118.07 & 15.6 & 22.981 \\
\hline Leverage & 126 & .00 & 399.7 & 22.79 & 66.93 \\
\hline
\end{tabular}

Variables definitions are reported in Table 1

\subsection{Correlation Analysis}

Table 3 explains the correlation analysis. It shows that the level of AAOIFI governance disclosure is positively correlated with board independence (B.IND) .385 and ACs .400, and 
these correlations are statistically significant at the $5 \%$ level. The correlations between level of AAOIFI governance disclosure and other governance and control variables are statistically insignificant.

Correlations between the independent and control variables do not show any evidence of multicollinearity. We also calculate the variance inflation factor (VIF). Based on previous studies (Field, 2009b; Gujarati, 2003) whether the VIF value is greater than 10, there is multicollinearity issue. We find that that the VIF value is higher than 1 and less than 10 (See Table 4). Therefore, there are no multicollinearity problems in this study. 
3Table 3: Pearson Correlation Matrix

\begin{tabular}{|c|c|c|c|c|c|c|c|c|c|c|c|}
\hline & Dis level & B.IND & B.SIZE & B.M & CEO & ACs & ACM & F.SIZE & LIQ & A.GRO & LEV \\
\hline $\mathbf{N}$ & 126 & 123 & 124 & 83 & 123 & 84 & 80 & 126 & 126 & 124 & 126 \\
\hline Dis level & 1 & $.385^{* *}$ & .080 & .161 & -.053 & $.400 * *$ & .193 & -.026 & -.018 & -.132 & -.162 \\
\hline B.IND & & 1 & .047 & -.192 & $-.321 * *$ & -.022 & $-.248 *$ & -.019 & .010 & -.124 & $-.193 *$ \\
\hline B.SIZE & & & 1 & .022 & $.323 * *$ & $.482 * *$ & .138 & .176 & -.135 & .154 & .069 \\
\hline B.M & & & & 1 & -.032 & .086 & .193 & .168 & -.174 & .145 & .073 \\
\hline CEO duality & & & & & 1 & .114 & -.003 & .093 & .036 & .108 & .055 \\
\hline ACs & & & & & & 1 & .167 & $.252^{*}$ & -.049 & .193 & -.119 \\
\hline $\mathrm{ACM}$ & & & & & & & 1 & .013 & -.021 & .183 & .123 \\
\hline F.SIZE & & & & & & & & 1 & -.101 & -.022 & -.059 \\
\hline LIQ & & & & & & & & & 1 & -.072 & -.043 \\
\hline A.GRO & & & & & & & & & & 1 & .078 \\
\hline LEV & & & & & & & & & & & 1 \\
\hline
\end{tabular}

Variables definitions are reported in Table 1

$* * *=$ significant at the $1 \%$ level

$* *$ significant at the $5 \%$ level

* = significant at the $10 \%$ level 


\subsection{Regression analysis}

We use Kolmogorov-Smirnov test to check the distrubution of our data. Table 4 illustrates that all the variables have a significant value of less than .05 , for example, the $p$-value for disclosure level, is 016 with a mean of 33 , which indicates that the variables are not normally distributed. So, we follow most of the previous disclosure studies (Pallant,2005) to transform control variables "Firm size" using log of the main value because be more close to normal distribution.

Table 5 presents our findings. The overall model was shown to be statistically significant, where the F-value was found to be $5.074(0.000)$, and the adjusted $R^{2}$ was found to be $51 \%$. This indicates that the independent variables explain $51 \%$ of the variation regarding the AAOIFI governance disclosure variable. This ratio is similar to the percentage reported by ElHalaby and Hussainey (2016) for $43 \mathrm{IBs}$ across eight countries (51\%). Moreover, it is higher than the percentage reported by Abdullah et al. (2015) for a sample of 157 IBs in the South East Asian and GCC regions (38\%). However, relatively, it is lower than the result of $61 \%$ that was reported by Scholtz and Smit (2015) in a study of sample companies listed on the Alternative Exchange in South Africa. In addition, it is important to check the Durbin-Watson autocorrelation; the Durbin-Watson statistic is always between 0 and 4 . The value in the current study is 1.614, which means there is no autocorrelation in the sample. According to Gujarati (2003), if the Durbin-Watson amount is equal or close to 2 then the null hypothesis of no autocorrelation will not be rejected. Although, the Durbin- Watson amount is low of the estimated model, the result of the correlation test does not mention the existence of important violation of the autocorrelation issue and the current result is consistent with AlBassam et al (2015) who found the values of Durbin-Watson are (.924; .950; .960; 1.012; $1.085 ; 1.316)$ 
4TABLE 4: NORMALITY TESTING ONE-SAMPLE KOLMOgOROV-SMIRNOV TEST

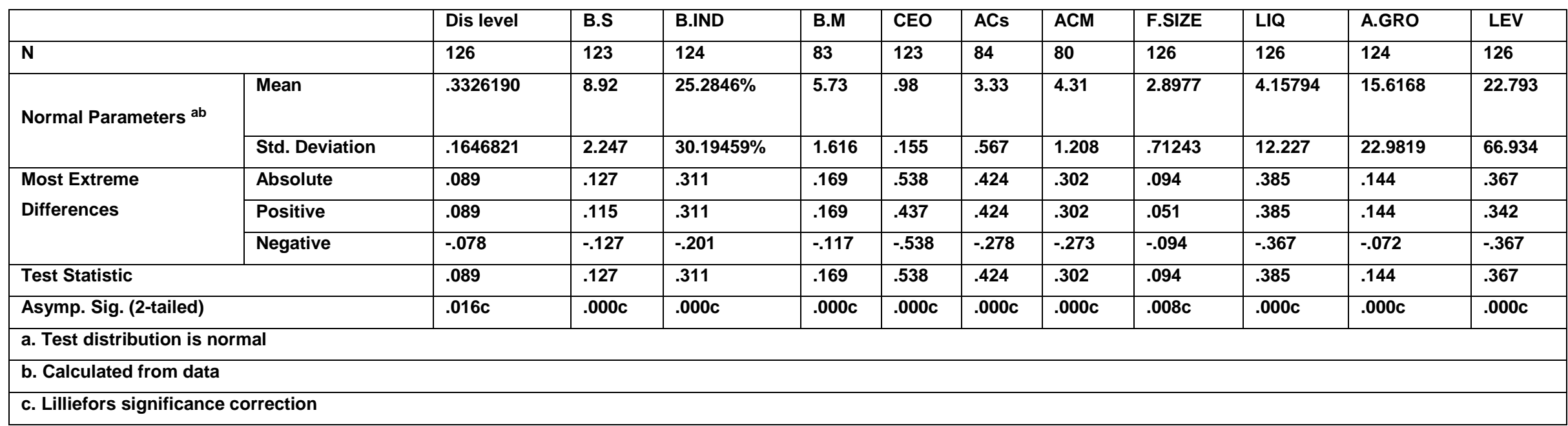

Variable definitions are reported in Table 1

$* * *=$ significant at the $1 \%$ level

$* *$ = significant at the $5 \%$ level

* = significant at the $10 \%$ level 
5TABLE 5: REgRESSION RESULT: DETERMINANTS OF AAOIFI GOVERNANCE DISCLOSURE

\begin{tabular}{|c|c|c|c|c|c|}
\hline & \multicolumn{2}{|c|}{$\begin{array}{l}\text { Unstandardised } \\
\text { Coefficients }\end{array}$} & \multirow[b]{2}{*}{ t-statistics } & \multirow[b]{2}{*}{ Sig. } & \multirow{2}{*}{$\begin{array}{c}\text { Collinearity } \\
\text { Statistics } \\
\text { VIF }\end{array}$} \\
\hline & B & Std. Error & & & \\
\hline (Constant) & .108 & .110 & .985 & .330 & \\
\hline Board independence & .000 & .001 & .305 & .762 & 3.286 \\
\hline Board size & -.003 & .007 & -.416 & .679 & 2.923 \\
\hline $\begin{array}{c}\text { Frequency of board } \\
\text { meeting }\end{array}$ & -.001 & .009 & -.090 & .928 & 1.858 \\
\hline CEO duality & .036 & .085 & .427 & .671 & 3.111 \\
\hline ACs & $.091^{\star \star \star}$ & .025 & 3.677 & .001 & 2.209 \\
\hline ACM & .007 & .010 & .713 & .479 & 1.455 \\
\hline Log Firm size & -.016 & .023 & -.717 & .477 & 2.710 \\
\hline Liquidity & .001 & .001 & 1.250 & .217 & 1.138 \\
\hline Asset growth & $-.001^{\star \star}$ & .001 & -2.403 & .020 & 1.792 \\
\hline Leverage & .000 & .000 & -.991 & .326 & 1.376 \\
\hline Fixed effect & $\begin{array}{c}\text { Year } \\
\text { and } \\
\text { country }\end{array}$ & \multirow{6}{*}{\multicolumn{4}{|c|}{ Dependent variable: AAOIFI governance disclosure }} \\
\hline Adjusted R-square & .505 & & & & \\
\hline R-square & .628 & & & & \\
\hline F-value & 5.074 & & & & \\
\hline F Sig & .000 & & & & \\
\hline Durbin-Watson & 1.614 & & & & \\
\hline
\end{tabular}

Variables definitions are reported in Table 1

The coefficient of board independence (B.IND) was found to be statistically insignificant. It indicates that board independence is not significantly associated with the AAOIFI governance disclosure level. In other words, the results show that the percentage of independent directors does not affect the level of AAOIFI governance disclosure. . Therefore, we reject the $\mathrm{H}_{1}$. This result is consistent with some previous studies, such as Solomon (2007), who stated that the level of disclosure does not increase in relation to the attendance of an independent board, due to some firms having a culture of disclosure and transparency. Similarly, Ho and Wong (2001) found an insignificant relationship between board independence and voluntary disclosure in listed firms in Hong Kong. The possible explanation of this result might suggest that independent directors at IBs are not qualified (e.g. have no Islamic Accounting or Finance degree and/or not a specialist in Islamic banking or have no 
awareness of AAOIFI standards) and therefore they are unable to suggest any improvement in disclosure levels.

The second coefficient of board size is -.003 , and this is insignificant at any level. This indicates that the number of board members does not affect the level of CG disclosure. This confirms the results obtained from Hassan et al. (2017) who found that board size does not affect voluntary disclosure. The reason for this result maybe because board members in Islamic banks do not have experience of AAOIFI governance and they may be interested in examining other issues such as the compliance with Sharia. Based on this study result, we reject $\mathrm{H} 2$.

For the third variable, namely board meeting frequency, it is found that it does not play a role in improving the extent of CG disclosure in IBs. The coefficient of the board meeting is found to be statistically insignificant. This result is consistent with Albawwat and Hussein (2015), who found the frequency of board meetings is insignificant with the level of voluntary disclosure in Jordanian listed companies. This result could be related to the previous result (board size), because if the board size is not interested in AAOIFI governance disclosure or is not experienced in AAOIFI governance, then it will not be discussed in the meetings; whether they meet once, twice or more times during the year, board meeting frequency will not affect the level of disclosure of AAOIFI governance.. This result leads us to reject $\mathrm{H} 3$.

Duality in position (CEO) is also found to be positive and insignificant, which is inconsistent with the study expectation that CEO duality issues lead to a higher CG disclosure. This result indicates that CEO duality does not affect the level of AAOIFI governance disclosure in IBs. This result may be due to the fact that IBs place more focus on the role of Sharia governance and the independence of SSB than duality in position; and, as a result, if there is duality in position in IBs, this does not affect the level of AAOIFI governance disclosure. In other words, Sharia governance is more significant than CG characteristics in IBs. Consequently, we reject H4.

For the fifth variable, that of ACS, the coefficient of ACS is found to be positive and statistically significant, at the $1 \%$ level. This indicates that the number of members on an audit committee affects the level of AAOIFI governance disclosure in IBs. The result is consistent with the arguments of the study and agency theory, which argues that ACS is one of the CG characteristics that reduce agency issues via developing disclosure, Barako et al. (2006). Also, the result of Al-Moataz and Hussainey (2012), in a sample of 97 financial reports in Saudi Arabia, found ACs to be the primary determinant of CG disclosure. This result indicates that a higher number of $A C$ lead to a higher level of $C G$ disclosure.

The possible explanation of this result is AAOIFI governance has sent a number of roles for AC members include [1] reviewing the interim and annual accounts and financial reports and [2] reviewing the IFIs accounting policies and practices and reporting requirements. Therefore, we believe that IBS will appoint members at AC who have relevant qualifications such as a degree in Islamic banking, Islamic Accounting, Islamic Finance as well as a good knowledge of AAOIFI standards. This indicates that the audit committee significantly affects the level of AAOIFI governance disclosure in IBs. Therefore, if there is a rise in the level of 
AAOIFI governance disclosure practice, IBs may have to increase their ACs. We therefore accept H5.

The ACM is found to be insignificant: this result indicates that ACM does not have an impact on the level of AAOIFI governance disclosure in IBs, which is inconsistent with this study's expectations that the more frequent the $A C M$, the greater the extent of $C G$ disclosure. This might indicate that in the ACM, the members discuss other non-financial reporting AAOIFI issues such as reviewing resources and skills, the scope of responsibility, overall work programme and reporting lines of the internal audit; reviewing the major outcome of an internal audit; reviewing the IFIs code of ethics and the effectiveness with which it is implemented; reviewing the effectiveness of the IFIs system for monitoring compliance with Sharia rules and principles; ensuring that independence and professional integrity of auditors is not compromised; Reviewing the compliance with Sharia rules and principles. This result leads to a rejection $\mathrm{H} 6$.

Regarding four control variables of firm characteristics, only one is found to be statistically significant, namely asset growth. The other three control variables, namely liquidity, firm size and leverage, are found to be statistically insignificant.

From the above analysis, it shows that ACS plays an important role in the IBs that mandatorily adopt AAOIFI standards to enhance AAOIFI governance disclosure. It is consistent with agency theory, that argues that ACS is one of the most important CG mechanisms that help to reduce agency problems by developing disclosure (Barako et al., 2006). In addition, agency theory Fama (1980) shows that larger audit firms have a stronger incentive to maintain their independence, and require more stringent and extensive disclosure standards.

The reason for this result may be due to the fact that IBs that mandatorily adopt AAOIFI standards, are following the standards with regard to this point, which requires there to be at least three audit committee members (AAOIFI, 2015). Also, there is a greater possibility that ACS leads to the disclosure of more information to all stakeholders because of the high level of accountability to ensure that IBs are compliant with Sharia. The other reason for this result may be because ACs in relation to IBs is unlike ACS in relation to non-IFIs, as the responsibility of ACS in IBs is not only to perform an audit of the financial information, but also to be compliant with sharia.

The analysis provides support for the arguments relating to agency which suggest that a large AC have better auditing performance standards than small AC (Fama, 1980). The outcomes showed a significant positive association between AAOIFI governance disclosure and ACs. The outcomes proved that the audit committee significantly affects the level of AAOIFI governance disclosure in IBs. Therefore, if there is a rise in the level of AAOIFI governance disclosure practice, IBs may have to increase their ACs.

The results shown in the current study can be useful for the role of the SSB in the IBs, because the SSB has the ability to review and confirm that all of the activities are completely compliant with Sharia rules. This means that the SSB could have the authority to prohibit and evaluate the banks' guidance when necessary. Otherwise, the SSB should disclose AAOIFI governance information to the public. To do so, IBs will highlight their AAOIFI governance standards, and that, in turn, will increase their reputation and improve the confidence of 
current clients and, as a consequence, engage with new investors and realise a higher level of trust from the public in IBs. This implication is supported by the result of El-Halaby et al. (2018) which suggested that IBs should improve the level of disclosure to engage more clients, based on their faith and loyalty of following sharia compliance.

\section{Conclusion}

This paper aims to examine the association between some CG mechanisms and the disclosure level of AAOIFI governance standards by IBs. The years of the study were 2013 to 2015 and involved 126 banks, including all IBs that have adopted AAOIFI's mandatory standards. However, the study excludes IBs in Lebanon, Tunisia and some banks in Sudan, because we could not access these banks' annual reports.

The current research contributes to Islamic accounting literature, by identifying the drivers for the disclosure of AAOIFI governance standards, and by considering the impact of bank governance on the disclosure level among IBs that mandatorily adopt AAOIFI standards. The study found that ACs was the only mechanism that was statistically significant and positive, and all of the other $C G$ characteristics were statistically insignificant. This result indicates that IBs that mandatorily adopt AAOIFI standards were following the standards with regard to this point, which requires there to be at least three members of an audit committee (AAOIFI, 2015). Also, there is a greater possibility that ACs in IBs leads to the disclosure of more information to all stakeholders because there is a high level of accountability to ensure that IBs are compliant with Sharia.

This study has a number of limitations that could be taken as avenues for future study such as this research depends on the annual reports only as a research source. Further research could include the collection of data from other sources, like websites, social networks and interim reports. Also, the current study focuses on IBs that mandatorily adopt the AAOIFI standards only, while there are other IBs that follow the AAOIFI standards voluntarily. Therefore, further research could compare the AAOIFI standards of compliant banks with non-compliant ones.

\section{References}

AAOIFI, A. (2015) 'The Accounting , Auditing and Governance Standards for Islamic financial institutions', AAOIFI, Bahrian.

Abdullah, W. A. W. (2013) 'Determinants of Corporate Governance Disclosure Practices of Islamic Banks', unpublished thesis Griffith University.

Abdullah, W. A. W., Percy, M. and Stewart, J. (2015) 'Determinants of voluntary corporate governance disclosure: Evidence from Islamic banks in the Southeast Asian and the Gulf Cooperation Council regions', Journal of Contemporary Accounting \& Economics, 11(3), 262279.

Albawwat and Hussein, A. (2015) 'Corporate Governance and Voluntary Disclosure of Interim Financial Reporting in Jordan', Journal of Public Administration and Governance, 5(2), 100127. 
Almanasir, A. H. A. and Shivaraj, B. (2017) 'Voluntary Corporate Governance Disclosure Innovative Evidence: The Case of Jordan', Journal of Reviews on Global Economics, 6, 443454.

Al-Bassam, W. M., Ntim, C. G., Opong, K. K. and Downs, Y. (2015) 'Corporate Boards and Ownership Structure as Antecedents of Corporate Governance Disclosure in Saudi Arabian Publicly Listed Corporations', Business \& Society, 1-43.

Al-Moataz, E. and Hussainey, K. (2012) 'Determinants of Corporate Governance Disclosure in Saudi Corporations', Journal of King Abdulaziz University: Economics \& Administration, 5(1), $52-84$

Allegrini, M. and Greco, G. (2013) 'Corporate boards, audit committees and voluntary disclosure: Evidence from Italian listed companies', Journal of Management \& Governance, 17(1), 187-216.

Al Qamashoui, A. and Hussainey, K. (2016) 'Determinants of AAOIFI/IFRS Adoption in Islamic Banking Industry', Portsmouth-Fordham Conference on Banking \& Finance, September 2016, Portsmouth Business School, Portsmouth University, UK.

Al-Janadi, Y., Rahman, R. A. and Omar, N. H. (2013) 'Corporate governance mechanisms and voluntary disclosure in Saudi Arabia', Research Journal of Finance and Accounting, 4(4), 2536.

Arcay, M. R. B. and Vazquez, M. F. M. (2005) 'Corporate characteristics, governance rules and the extent of voluntary disclosure in Spain', Advances in Accounting, 21, 299-331.

Bahari, N. F. and Baharudin, N. A. (2016) ' Shariah Governacne Framework:The Roles of Shariah Review and Shariah Auditing', Proceeding of the 3rd International Conference on Management \& Muamalah. (pp. 375-381).

Barako, D. G., Hancock, P. and Izan, H. (2006) 'Factors influencing voluntary corporate disclosure by Kenyan companies', Corporate Governance: An International Review, 14(2), 107-125.

Baydoun, N. and Willett, R. (2000) 'Islamic corporate reports', Abacus, 36(1), 71-90.

Bhatti, M. and Bhatti, I. (2009) 'Development in legal issues of corporate governance in Islamic finance', Journal of Economic and Administrative Sciences', 25(1), 67-91.

Cadbury, A.( 2002) 'Corporate governance and chairmanship: A personal view'. Oxford University Press on Demand.

Chapra, M. Umer. and Ahmed, H. (2002) 'Corporate governance in Islamic financial institutions', Occasional paper, 6. IRTI: Jeddah, Saudi Arabia: Islamic Development Bank

Donker, H. and Zahir, S. (2008) 'Towards an impartial and effective corporate governance rating system', Corporate Governance: The international journal of business in society, 8(1), 83-93. 
El-Halaby, S. and Hussainey, K. (2016) 'Determinants of compliance with AAOIFI standards by Islamic banks', International Journal of Islamic and Middle Eastern Finance and Management, 9(1), pp.143-168.

El-Halaby, S, Hussainey, K \& Abou-El-Sood, H (2018) 'The non-economic consequences of disclosure in Islamic banks' International Journal of Emerging Markets. 13(6), pp.1948-1968.

Elfeky, M. I. (2017) 'The extent of voluntary disclosure and its determinants in emerging markets: Evidence from Egypt', The Journal of Finance and Data Science. 3(1-4), pp.45-59.

Elzahar, H. and Hussainey, K. (2012) 'Determinants of narrative risk disclosures in UK interim reports', The Journal of Risk Finance, 13(2), 133-147.

Eng, L. L. and Mak, Y. T. (2003) 'Corporate governance and voluntary disclosure', Journal of Accounting and Public Policy, 22(4), 325-345.

Ezat, A. and El-Masry, A. (2008) 'The impact of corporate governance on the timeliness of corporate internet reporting by Egyptian listed companies', Managerial Finance, 34(12), 848867.

Fama, E. F. (1980) 'Agency problems and the theory of the firm', Journal of political economy, 88(2), 288-307.

Fama, E. F. and Jensen, M. C. (1983) 'Agency problems and residual claims', The Journal of Law and Economics, 26(2), 327-349.

Field, A. (2009b) 'Logistic regression', Discovering statistics using SPSS, 264, 315.

Fiori, G., Izzo, M. F. and di Donato, F. (2016) 'Exploring the Effects of Corporate Governance on Voluntary Disclosure: An Explanatory Study on the Adoption of Integrated Report' in Performance Measurement and Management Control: Contemporary Issues, 83-108.

Garcia-Meca, E. and Sanchez-Ballesta, J. P. (2010) 'The association of board independence and ownership concentration with voluntary disclosure: A meta-analysis', European Accounting Review, 19(3), 603-627.

Gisbert, A. and Navallas, B. (2013) 'The association between voluntary disclosure and corporate governance in the presence of severe agency conflicts', Advances in Accounting, 29(2), 286-298.

Grais, W. and Pellegrini, M. (2006) 'Corporate governance in institutions offering Islamic financial services: issues and options', World Bank Publications.

Gray, R., Kouhy, R. and Lavers, S. (1995) 'Corporate social and environmental reporting: a review of the literature and a longitudinal study of UK disclosure', Accounting, Auditing \& Accountability Journal, 8(2), 47-77. 
Greco, G. (2011) 'Determinants of board and audit committee meeting frequency: Evidence from Italian companies', Managerial Auditing Journal, 26(3), 208-229.

Gujarati, D. (2003) 'Basic econometrics', (4th edition), McGraw-Hill, Boston. United states Military Academy. West Point.

Gul, F. A. and Leung, S. (2004) 'Board leadership, outside directors' expertise and voluntary corporate disclosures', Journal of Accounting and Public Policy, 23(5), 351-379.

Hasan, Z. (2011) 'A survey on Shari'ah governance practices in Malaysia, GCC countries and the UK: Critical appraisal', International Journal of Islamic and Middle Eastern Finance and Management, 4(1), 30-51.

Hasan, R., Sharmeen, K. and Sultana, A. (2017b) 'Influence of Internal and External Governance Mechanisms on Corporate Governance Disclosure among Islamic and Conventional Banks', Global Review of Islamic Economics and Business, 5(1), 25-36.

Hashim, H. A. and Devi, S. S. (2008) 'Board independence, CEO duality and accrual management: Malaysian evidence', Asian Journal of Business and Accounting, 1(1), 27-46.

Haniffa, R. M. and Cooke, T. E. (2002) 'Culture, corporate governance and disclosure in Malaysian corporations', Abacus, 38(3), 317-349.

Haniffa, R. and Hudaib, M. (2007) 'Exploring the Ethical Identity of Islamic Banks via Communication in Annual Reports', Journal of Business Ethics, 76(1), 97-116.

Healy, P. M. and Palepu, K. G. (2001) 'Information asymmetry, corporate disclosure, and the capital markets: A review of the empirical disclosure literature', Journal of accounting and economics, 31(1-3), 405-440.

Ho, S. S. and Wong, K. S. (2001) 'A study of corporate disclosure practice and effectiveness in Hong Kong', Journal of International Financial Management \& Accounting, 12(1), 75-102.

Jensen, M. C. and Meckling, W. H. (1976) 'Theory of the firm: Managerial behavior, agency costs and ownership structure', Journal of financial economics, 3(4), 305-360.

Joshi, P. L., Sallah, N. M. Z., Hamzah, H., Wasiuzzaman, S. and Krishnan, A. (2016) 'Determinants of compliance and disclosure requirements by top listed companies under Malaysian Code of Corporate Governance (2012)', Afro-Asian Journal of Finance and Accounting, 6(2), 135-159.

Kanagaretnam, K., Lobo, G. J. and Whalen, D. J. (2007) 'Does good corporate governance reduce information asymmetry around quarterly earnings announcements?', Journal of Accounting and Public Policy, 26(4), 497-522. 
Khan, A., Muttakin, M. B. and Siddiqui, J. (2013) 'Corporate governance and corporate social responsibility disclosures: Evidence from an emerging economy', Journal of Business Ethics, 114(2), 207-223.

Khanchel, I. (2007) 'Corporate governance: measurement and determinant analysis', Managerial Auditing Journal, 22(8), 740-760.

Krause, R., Semadeni, M. and Cannella Jr, A. A. (2014) 'CEO duality: A review and research agenda', Journal of Management, 40(1), 256-286.

Laksmana, I. (2008) 'Corporate board governance and voluntary disclosure of executive compensation practices', Contemporary accounting research, 25(4), 1147-1182.

Li, J., Mangena, M. and Pike, R. (2012) 'The effect of audit committee characteristics on intellectual capital disclosure', The British Accounting Review, 44(2), 98-110.

Lipton, M. and Lorsch, J. W. (1992) 'A modest proposal for improved corporate governance', The business lawyer, 59-77.

Mangena, M. and Pike, R. (2005) 'The effect of audit committee shareholding, financial expertise and size on interim financial disclosures', Accounting and Business Research, 35(4), 327-349.

Mollah, S. and Zaman, M. (2015) 'Shari'ah supervision, corporate governance and performance: Conventional vs. Islamic banks'. Journal of Banking \& Finance, 58, pp.418435 .

Nejati, M. (2013a) 'The Effects of Perceptions Towards Social Responsibility and Stakeholders' Influence on Responsible Business Behaviours of Micro, Small and Medium-sizes Enterprises (MSMES) in Malaysia and Their Financial and Non-financial Outcomes' unpublished thesis Universiti Sains Malaysia.

Ntim, C. G. and Soobaroyen, T. (2013) 'Black economic empowerment disclosures by South African listed corporations: The influence of ownership and board characteristics', Journal of Business Ethics, 116(1), 121-138.

OECD, O. (2004)'The OECD principles of corporate governance. Contaduría y Administración', (216).

Othman, R., Ishak, I. F., Arif, S. M. M. and Aris, N. A. (2014) 'Influence of audit committee characteristics on voluntary ethics disclosure', Procedia-Social and Behavioral Sciences, 145, 330-342.

Pallant, J.,( 2005) 'SPSS Survival Manual: A Step By Step Guide to Data Analysis Using SPSS for Windows' (Version12). 
Peasnell, K. V., Pope, P. F. and Young, S. (2005) 'Board monitoring and earnings management: Do outside directors influence abnormal accruals?', Journal of Business Finance \& Accounting, 32(7-8), 1311-1346.

Peng, M. W., Zhang, S. and Li, X. (2007) 'CEO duality and firm performance during China's institutional transitions', Management and Organization Review, 3(2), 205-225.

Rahma, A. A. n. and Bukair, A. A. (2015) 'The Effect of the Board of Directors' Characteristics on Corporate Social Responsibility Disclosure by Islamic Banks', Journal of Management Research, 7(2), 506-519.

Saeed, A. (1996) 'Islamic banking and interest: A study of the prohibition of riba and its contemporary interpretation', (Vol. 2) Brill.

Safieddine, A. (2009) 'Islamic financial institutions and corporate governance: New insights for agency theory', Corporate Governance: An International Review, 17(2), 142-158.

Salin, A. S. A. P., Shaharb, N. A. and Nawawi, A. (2017) 'Shari'a Compliance on Corporate Governance Disclosure: an Empirical Evidence of Malaysian IFIs', 289-295.

Samaha, K., Dahawy, K., Hussainey, K. and Stapleton, P. (2012) 'The extent of corporate governance disclosure and its determinants in a developing market: The case of Egypt', Advances in Accounting, 28(1), 168-178.

Sarker, A. A. (2000) 'Regulation of Islamic banking in Bangladesh: role of Bangladesh bank', International Journal of Islamic Financial Services, 2(1), 67.

Scholtz, H. and Smit, A.-R. (2015) 'Factors influencing corporate governance disclosure of companies listed on the Alternative Exchange (AltX) in South Africa', South African Journal of Accounting Research, 29(1), 29-50.

Srairi, S. (2015) 'Corporate Governance Disclosure Practices and Performance of Islamic Banks in GCC Countries', Journal of Islamic Finance, 4(2), 001-017.

Solomon, J. (2007) 'Corporate governance and accountability', John Wiley \& Sons.

Sulub, S., Salleh, Z. and Hashim, H.A. (2018) 'Determinants of Corporate Governance Disclosures of Islamic Banks in Sudan: Implications for Shariah Governance'. Afro-Asian Journal of Finance and Accounting (Forthcoming).

Wang, M. and Hussainey, K. (2013) 'Voluntary forward-looking statements driven by corporate governance and their value relevance', Journal of Accounting and Public Policy, 32(3), 26-49.

Watson, A., Shrives, P. and Marston, C. (2002) 'Voluntary disclosure of accounting ratios in the UK', The British Accounting Review, 34(4), 289-313. 
Welker, M. (1995) 'Disclosure policy, information asymmetry, and liquidity in equity markets', Contemporary accounting research, 11(2), 801-827.

Zainuldin, M.H., Lui, T.K. and Yii, K.J. (2018) 'Principal-agent relationship issues in Islamic banks: a view of Islamic ethical system', International Journal of Islamic and Middle Eastern Finance and Management, 11(2), pp.297-311.

Zaheer, N. (2013) 'Effects of duality, board size and board composition on corporate governance disclosure in Pakistan', International SAMANM Journal of Finance and Accounting, 1(3), 1-16. 